\title{
CORRESPONDENCE
}

\section{Mesozoic stratigraphy of Eastern Svalbard: a reply}

SIR - We are grateful to Edwards et al. (this issue) for a preview of their paper in which they object to the nomenclature and classification of lithostratigraphic units that we have employed to describe the Mesozoic sequence in Svalbard. They present an alternative scheme in which they also take note of new data. In certain respects, therefore, we are bound to accept their suggestions, but in some others we argue below that their criticism is not well based.

In parts of this discussion there is clearly room for more than one opinion; we debated between ourselves what descriptive scheme we should employ at the time of our publication (1975-6), and we now argue that in the interests of stability a scheme proposed as part of a new and systematic description should stand until an altogether more thorough study supersedes it. This has been policy since our group's first substantial publication on the Mesozoic geology of the region in 1965 (Buchan et al.).

Our conclusions are summarized in two tables, which modify where necessary, but retain the original scheme where we consider it will serve beneficially. We also include, in anticipation, the scheme from another paper submitted in 1976 and accepted for publication as a Skrifter of the Norsk Polarinstitutt. This has already (informally) met with similar criticism, so we anticipate and attempt to justify what we have done. However, all in all, these are matters of convention rather than positive substance, and so we do not overestimate their importance. We are primarily concerned at the confusion that has arisen through the presentation of alternative schemes.

In our papers we have followed current guides to stratigraphic procedure (e.g. Harland et al. 1972; Hedburg, 1976) in regarding the formation as the primary local rock unit that should be internally (relatively) homogenous, externally distinguishable and presumed to have originally been physically continuous. Other visible variations within the formation are recognized by member status. We do not regard age as a valid criterion with which to divide or combine otherwise distinctive units. We prefer to define the units by all characters (including fossils) and then begin or continue discussion on age, environment, etc. Thus a subsequent change of opinion as to the age of a particular unit does not automatically require a change in the name or rank of that unit. Indeed, after careful consideration, we decided to introduce new formational names for different, widely scattered areas on the basis of recognizable differences. A major factor in the argument of Edwards $e t$ al. is that because these formations are all about the same age they should have the same name - i.e. one should therefore extend the Spitsbergen nomenclature to the other islands of the archipelago. They argue also that it will be easier to remember fewer names, but for this function we consider that as there are already many formational names in Svalbard the memory need not be burdened with other than group names. So we unite our different formations in each area into groups that extend throughout the region. This is convenient for descriptive and especially comparative purposes. We discuss the formations individually below under the group names that have been accepted from earlier schemes.

\section{Adventdalen Group}

Firstly, we agree that our Kong Karls Land Formation is probably of similar age (Barremian) to the Helvetiafjellet Formation of Spitsbergen, but it is dominated by the presence of lava flows whereas none has been recorded in the Helvetiafjellet Formation. We regard lava flows as an integral part of the formation and quite distinct from other basic rocks that prove to be sills. There are other (lesser) differences and all in all we stand by our distinction. On the other hand, we are ready to concede that our division into three members is not really necessary - though we find it useful for detailed description and comparison. It can be avoided by using more words, but in this connexion we prefer to leave matters as they stand - for we cannot retract a definition. Those who do not wish to distinguish the members within the formation need not do so, but for those who so wish the names are available. The future will tell what practice is acceptable, but in any case in such a hierarchy we expect group names to be used mostly (regionally) and member names to be used least (locally).

Secondly, Edwards et al. equate our Kongsoya Formation with the Janusfjellet Formation of Spitsbergen (indeed we ourselves suggested a close correlation). The distance between these outcrops, however, is over $100 \mathrm{~km}$ and the sequences within the formations are different (though admittedly not so strikingly different

Geol. Mag. 116 (l), 1979, pp. 55-61. Printed in Great Britain. 


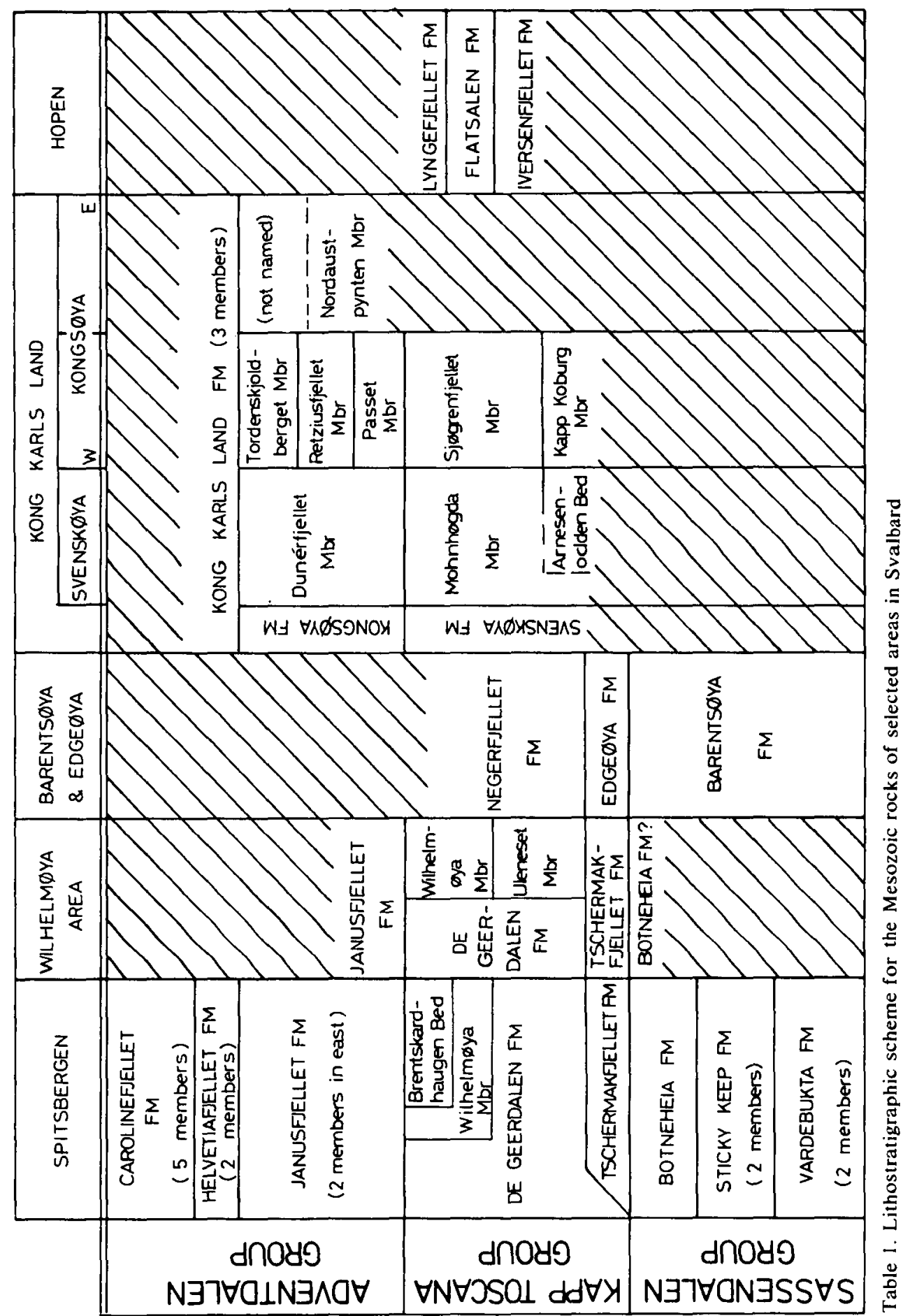




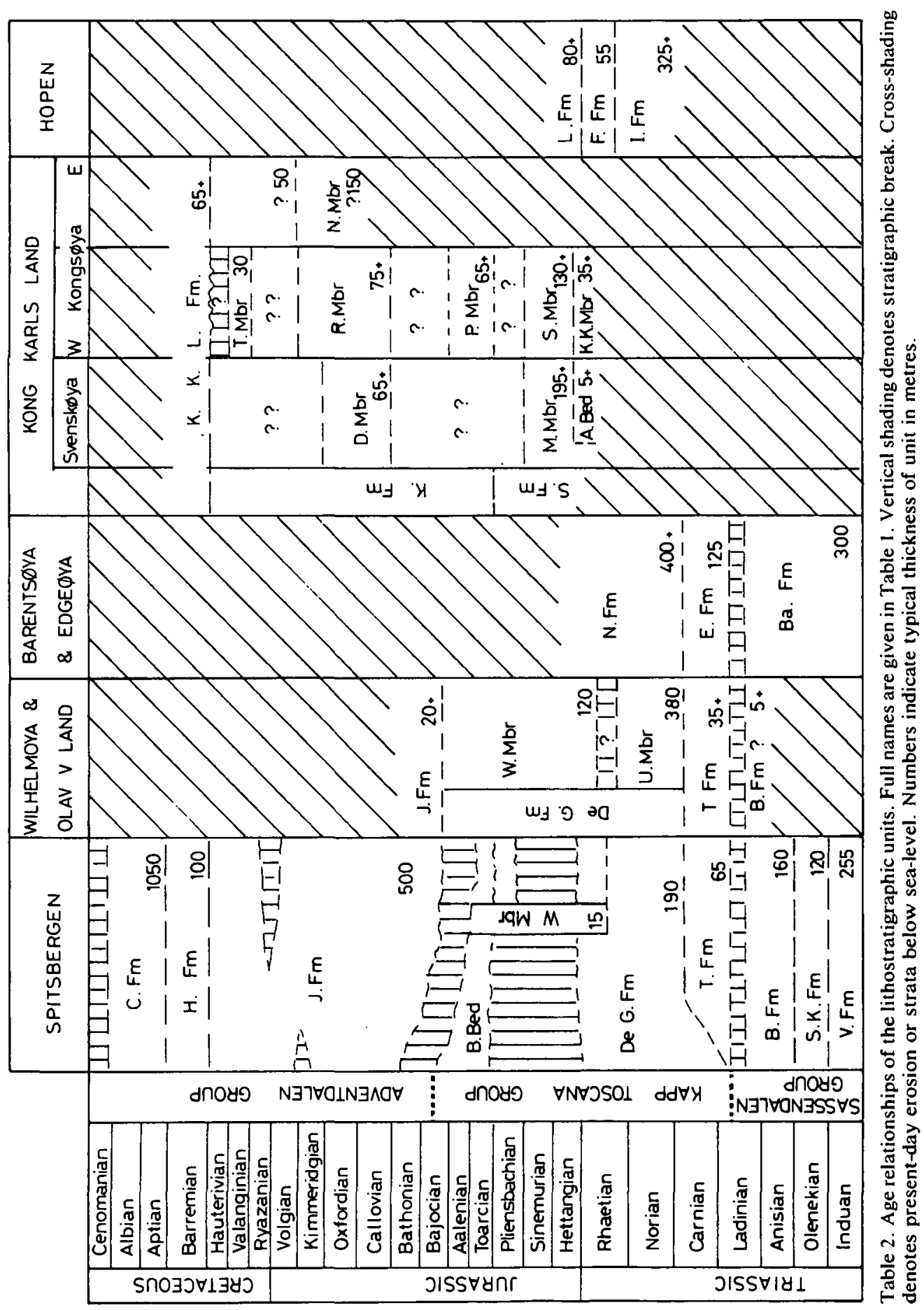


as is the case with the formations above and below). We divided the Kongsoya Formation into members, which are criticized on the basis that we included a lithological term as an aid (e.g. our Retziusf jellet Shale Formation is not all shale) - yet the formal version of such a name must exclude the lithological term (Harland et al. 1972, p. 299). The same applies to the Tordenskjoldberget Limestone Member. Limestone happens to be a distinctive element in this unit and is not otherwise common in the Adventdalen Group of Spitsbergen. Thus it is appropriate to use the term even though the unit is not composed entirely of limestone. Such practice is common elsewhere.

\section{The Kapp Toscana Group}

Apart from Birkenmajer (1977), who wished to incorporate the lower part of the Kapp Toscana and all of the Sassendalen Group into a local group for SW Spitsbergen, it seems that most investigators recognize the same, regionally significant unit. Indeed, it is the use of units of group status that allows us to signify the unity of the Barents Shelf platform-type sedimentation in Mesozoic time.

The lower boundary of the Kapp Toscana Group is a stratigraphic break that does not seem to be in question. Similarly, we all appear agreed upon the top boundary (see discussion by areas below) except perhaps for the Kong Karls Land area. Here the lack of a Brentskardhaugen Bed marker leaves the boundary unclear. We cannot accept the suggestion of Edwards et al. that the Passet Member be included in the top of the Kapp Toscana Group, for this is an example of the very problem we are trying to avoid with a lithostratigraphic scheme - namely changing the scheme on the basis of new evidence of age. Certainly the Passet Member is sandy, but we still feel it is more assignable to the bottom of the Adventdalen Group being (a) marine and $(b)$ as much argillaceous as sandy.

The other major difference of opinion that therefore remains is whether or not there is a regionally recognizable horizon within the Kapp Toscana Group, i.e. the Wilhelmøya/De Geerdalen boundary of Edwards et al. We maintain that such a boundary depends more upon interpretation than observation, and that it may not be distinguishable at all in places. If it could be demonstrated as a clearly mappable horizon we would accept it, but as considerable stretches of water intervene between the various major outcrops, 'mappability' cannot be easily demonstrated.

\section{2.a. Spitsbergen}

In Spitsbergen we recognize three units which comprise the Kapp Toscana Group. In most areas of central and eastern Spitsbergen the group is divided into two formations (Harland et al. 1974), namely a lower marine shale (Tschermakfjellet Formation) and an upper continental sandstone (De Geerdalen Formation). In parts of western Spitsbergen the marine shale unit is apparently lacking, and deposits of De Geerdalen type represent the whole of the Kapp Toscana Group. The Brentskardhaugen Bed (Parker, 1967= 'Lias Conglomerate') is included in the top of the De Geerdalen Formation whenever present. This may not be correct from the sedimentological point of view, as the bed represents the start of a transgression. However, from a purely descriptive point of view the bed consists of reworked Kapp Toscana material, and is therefore included as part of the same lithological unit.

Bjærke \& Dypvik (1977) proposed that a further unit, the Wilhelmøya Member (sic) be recognized in the Sassendalen area (E. Spitsbergen). This would consist of the Brentskardhaugen Bed, a few metres of early Jurassic and Rhaetian shales below it, and a phosphorite conglomerate at the base. Such a unit need not be accorded formation status (having not even been noticed before) but is certainly of importance. Bjarke \& Dypvik suggested it might be recognized as the Wilhelmoya Member of the Kapp Toscana Formation (sic), yet wished to retain a Wilhelmøya Formation further east. However, the practice of naming a unit as a formation in one area and a member in another we find unacceptable. We prefer to recognize the unit as the Wilhelmoya Member of the De Geerdalen Formation where it is distinguished. The Brentskardhaugen Bed thus becomes the upper part of this member in the Sassendalen area. Should subsequent investigations distinguish a similar unit in other parts of Spitsbergen, then the member may be recognized without the need to alter the lithostratigraphic scheme further or to redefine the De Geerdalen Formation.

\section{2.b. Wilhelmoya and easternmost Spitsbergen}

In Wilhelmoya and eastern Olav $V$ Land (eastern Spitsbergen) v'e also recognize the Wilhelmoya unit, but again as a member (Smith, 1975) of the De Geerdalen Formation. We do this, despite the fact that the Wilhelmoya unit is an important one here, to facilitate correlation to Spitsbergen where the unit is not so well developed and is only allotted member status. Although the $34 \mathrm{~m}$ of shale below the Uleneset Member 
and above sea level in this area do not contain the characteristic, abundant, red-weathering ironstone nodules, these may be included in the Tschermakfjellet Formation by extrapolation.

\section{2.c. Hopen and Kong Karls Land}

As to these outlying islands, it remains our contention that the exposures are sufficiently distinct and distant for the units recognized not to be helpfully classified with the formation names used in Spitsbergen. Although the Lyngefjellet and Flatsalen Formation in Hopen may well be of the same age as the Wilhelmoya Formation (as suggested by Smith, 1975), it is still not conclusively demonstrable that they are part of a once-continuous unit of identical facies. We thus prefer to retain the three formations recognized by Smith (1975) for Hopen. Kong Karls Land is well to the east of Spitsbergen, and we prefer to retain the Svenskeya Formation for Kapp Toscana Group deposits in that area because they are distinctive in consisting of a loose, porous sand. This formation is then represented by the Mohnhogda Member and Arnesenodden Bed on Svenskoya. On Kongsoya only the Sjogrenfjellet Member was recognized by Smith et al. (1976). We accept the addition of a new member (at the base of the exposure) by Worsley \& Heintz (1977), and it may be noted in passing that Worsley \& Heintz called this unit the Kapp Koburg Member, although it is at the same level as our Arnesenodden Bed and the same Arnesenodden was therefore already available.

Ultimately it is hoped that the geology of the offshore areas between these islands and Spitsbergen will be resolved. Thus the lithostratigraphic scheme employed for the land areas must make allowance for the possibility that new data will lead to new interpretation. Any current scheme must not pre-empt such investigations.

\section{2.d. Barentsoya and Edgeoya}

The sequence in these islands is described in Lock et al. (in press). The Kapp Toscana Group is the youngest pre-Quaternary unit seen on the islands, and is divided into a lower shale unit (Edgeoya Formation) and an upper sandstone unit (Negerfjellet Formation). These two units are again comparable to units of the same age in Spitsbergen, the former to the Tschermakfjellet Formation, the latter to the De Geerdalen Formation. While easy to correlate approximately, they are, however, of distinctive facies so that description, comparison and correlation is made easier by a distinct name, thus: 'Edgeoya Formation' rather than 'the Tschermakfjellet Formation in Edgeøya and Barentsøya', with the corresponding need to refer to the 'Tschermakfjellet Formation in Spitsbergen'.

\section{2.e. The WilhelmoyalDe Geerdalen boundary of Edwards et al.}

As mentioned above, the primary cause of controversy over the Kapp Toscana Group is the claim of Edwards $e t$ al. to recognize two distinct formations above the marine shale at the base of the Kapp Toscana Group in eastern Svalbard, namely their Wilhelmoya and De Geerdalen Formations. They claim a sharp contact which may be visibly erosive. On Hopen, however, this 'contact' is merely the junction between successive coarsening-upwards cycles, and in fact the junction as originally specified by Worsley (1973) was taken within such a cycle (i.e. the Hopen equivalent of the basal member of his new Wilhelmoya Formation was a shelly calcareous sandstone which forms the top of a coarsening-upward cycle). Bjærke (1975) unfortunately maintained this definition, though Edwards et al. appear to have accepted the definition of the Flatsalen Formation of Smith et al. (1976). However, Bjærke redefined the Flatsalen Formation to take in this 'basal bed', and Edwards $e t$ al. may therefore be using this redefinition.

Even if the base of the 'Wilhelmoya Formation' on Hopen is taken at the base of the Flatsalen Formation of Smith et al. (1976), then it is no more (nor less) of a hiatus or erosion surface than the tops of numerous preceding cycles or of the three succeeding ones which make up our Flatsalen Formation. The more obvious facies change comes at the base of the Lyngefjellet Formation, which marks a change from marine to fluviatile conditions. The same argument can also be applied to the Wilhelmoya succession, where the Tumlingodden Member (Worsley, 1973) is the really distinctive unit, although it still falls well within the circumscription of the De Geerdalen Formation.

The question of mapping the critical horizon (i.e. the De Geerdalen/Wilhelmøya Formation boundary of Edwards $e t$ al.) between the two key localities of Hopen and Wilhelmoya is passed over by Edwards $e t$ al. with merely the observation that 'Hopen is much less distant from Edgeøya'. Even so, there is still $100 \mathrm{~km}$ of open sea between Hopen and the southernmost part of Edgeøya - quite sufficient to allow important facies changes. Moreover, it is not clear that the 'Wilhelmoya Formation' can be recognized on Edgeoya. Cambridge investigations, reported by Lock et al. (in press), do not recognize a Flatsalen/Bjernbogen type of lithological unit in S Edgeoya, where the highest beds of that island are seen. Probable fluviatile sandstones 
are, however, present in these higher beds (Negerfjellet Formation: defined by Lock $e t$ al.), and this would seem to make it even less likely that the Flatsalen and Bjornbogen units were originally continuous across Edgeøya. The shale-with-ironstone facies of these two units occurs repeatedly throughout the Kapp Toscana Group but, with the exception of the Tschermakf jellet and Edgeoya Formations (latter defined by Lock et al.), is generally of local extent only. The possibility remains of a regionally extensive unit of this type, of approximately Rhaetian age, consisting of Bjornbogen, Flatsalen, Arnesenodden and Kapp Koburg units plus the beds immediately below the Brentskardhaugen Bed in the Sassendalen area. However, to include all the scattered fragments of this facies under the same name is to base the nomenclature on an interpretation which was not initially justified.

Edwards et al. further insist that clast content provides an important lithological distinction between their Wilhelmøya and De Geerdalen Formations. Certainly there is a contrast between basal De Geerdalen sandstones (rich in feldspar and rock fragments) and the fluviatile sandstones at the top of the group in Hopen and Wilhelmøya (quartz predominant). However, Pchelina (1965) has already pointed out that there is a gradual increase in quartz content throughout the Carnian-Rhaetian interval (her ' $T_{3}$ '). In addition the question of interpretation rather than observation arises again; Edwards et al. say the change is due to a significant change in environment, but a gradual wearing down of the source area provides just as likely an explanation. The history of the Kapp Toscana Group, after all, sees a change from a relatively abundant sediment supply to an environment lacking in terrigenous sediments (allowing phosphorites to form). The supposed lithostratigraphic boundary then again turns largely on points of interpretation rather than observation. The only regionally applicable definition of the De Geerdalen-Wilhelmøya boundary of Edwards et al. is based on environmental assumptions, not easy for recognition of local rock units in the field.

Even on the environmental interpretation there is no clear-cut solution. Edwards et al. suggest contrasting depositional environments for the two formations, but we would suggest that both of their formations contain examples of each other's 'characteristic facies'. For instance, sediments formed in estuaries, beaches, lagoons, barriers and tidal flats can certanly be found in the Negerfjellet Formation of Edgeoya (Lock et al.) and probably in the Iversenfjellet Formation of Hopen too. Deltaic sediments, on the other hand, occur in the Tumlingodden and Lyngefjellet units, and probably in the Svenskøya Formation as well. We do not envisage any major change of regime, and feel that Edwards et al. have exaggerated one of a series of changes (both lateral and vertical) to distinguish their two 'formations'.

\section{The Sassendalen Group}

Although formations in this group were not discussed by Edwards et al. we anticipate analogous criticism of the Barentsoya Formation, a shale unit defined by Lock et al. (in press) to represent the entire Sassendalen Group in Barentsoya and Edgeøya. This is the lowest of three formations first distinguished by Falcon in 1928 as the 'bituminous shales'. Flood, Nagy \& Winsnes (1971) further divided these rocks into three units with names adapted from (but of different rank to) the units defined by Buchan et al. (1965) in Spitsbergen. This also seemed to be an exercise in correlation rather than mapping, but discussion of this is left to Lock et al.

\section{Conclusions}

A lithostratigraphic scheme must stand or fall on the basis of its use in the field by subsequent workers on the same rock units, the framework of defined rock units being the only framework to which workers may subsequently relate their own findings. We have found our scheme of locally defined units to be practicable when describing the rocks and we have gratefully adopted names of schemes when they were published prior to our own work. We consider our scheme to be an adequate and objective means of describing the appearance of this part of the Mesozoic succession in the field, and we think that Edwards $e t$ al. are applying names to concepts rather than to distinguishable rock units.

\section{References}

Birkenmajer, K. 1977. Triassic sedimentary formations of the Hornsund area, Spitsbergen. Studia geol. polon. 41, 7-74.

Bjærke, T. 1975. Atlas of palynomorphs from the Upper Triassic of Hopen, Svalbard. Rep. NTNF Cont. Shelf Project, Trondheim. 
Bjærke, T. \& Dypvik, H. 1977. Sedimentological and palynological studies of Upper Triassic-Lower Jurassic sediments in Sassenf jorden, Spitsbergen. Arb. norsk Polarinst. 1976, 131-50.

Buchan, S. H., Challinor, A., Harland, W. B. \& Parker, J. R. 1965. The Triassic stratigraphy of Svalbard. Skr. norsk Polarinst. 135, 1-92.

Edwards, M. B., Bjærke, T., Nagy. J., Winsnes, T. S. \& Worsley, D. 1979. Mesozoic stratigraphy of eastern Svalbard: a discussion. Geol. Mag. 116, $49-54$ (this issue).

Falcon, N. L. 1928. Geology. In H. G. Watkins: The Cambridge Expedition to Edge Island. Geogr. J. 72, 134-9.

Flood, B., Nagy, J. \& Winsnes, T. S. 1971. The Triassic succession of Barentsoya, Edgeoya and Hopen (Svalbard). Meddr. norsk Polarinst. 100.

Harland, W. B. (Chairman) and others. 1972. A concise guide to stratigraphical procedure. Jour. geol. Soc. 128, 295-305.

Harland, W. B., Cutbill, J. L., Friend, P. F., Gobbett, D. J., Holliday, D. W., Maton, P. I., Parker, J. R. \& Wallis, R. H. 1974. The Billefjorden Fault Zone, Spitsbergen. Skr. norsk Polarinst. 161.

Hedberg, H. D. (ed.) 1976. International Stratigraphic Guide. International Subcommission on Stratigraphic Classification of IUGS Commission on Stratigraphy. Wiley.

Lock, B. E., Pickton, C. A. G., Smith, D. G., Batten, D. J. \& Harland W. B. (in press). The Geology of Barentsoya and Edgeoya, Svalbard. Skr. norsk Polarinst.

Parker, J. R. 1967. The Jurassic and Cretaceous sequence in Spitsbergen. Geol. Mag. 104, 487-505.

Pchelina, T. M. 1965. Stratigraphy and composition of the Mesozoic deposits in central Vestspitsbergen. In Geology of Spitsbergen 1965 (ed. Sokolov). In Russian. English translation by National Lending Library (ed. Harland), Boston Spa (1970), pp. 13I-54.

Smith D. G. 1974. Late Triassic pollen and spores from the Kapp Toscana Formation, Hopen, Svalbard. Rev. Palaeont. Palynol. 17, 175-8.

Smith, D. G. 1975. The stratigraphy of Wilhelmoya and Hellwaldf jellet, Svalbard, Geol. Mag. 113, 481-9l.

Smith, D. G., Harland, W. B., Hughes, N. F. \& Pickton, C. A. G. 1976. The Geology of Kong Karls Land, Svalbard. Geol. Mag. 113, 193-232.

Worsley, D. 1973. The Wilhelmøya Formation - a new lithostratigraphical unit from the Mesozoic of eastern Svalbard. Arb. norsk Polarinst. 1971, 7-16.

Worsley, D. \& Heintz, N. 1977. The stratigraphical significance of a marine vertebrate fauna of Rhaetian age, Kong Karls Land. Arb. norsk Polarinst. 1976, 69-82.

C. A. G. PICKTON
W. B. HARLAND
N. F. HUGHES

Department of Geology

Sedgwick Museum

Downing Street

Cambridge

England

7 June 1978
D. G. SMITH

Trinity College

Dublin 2

Ireland 